\title{
Comparison of microstructural evolution of fuel electrodes in solid oxide fuel cells and electrolysis cells
}

Trini, M.; Hauch, A.; De Angelis, S.; Tong, X.; Hendriksen, P. Vang; Chen, M.

Published in:

Journal of Power Sources

Link to article, DOI:

10.1016/j.jpowsour.2019.227599

Publication date:

2020

Document Version

Peer reviewed version

Link back to DTU Orbit

Citation (APA):

Trini, M., Hauch, A., De Angelis, S., Tong, X., Hendriksen, P. V., \& Chen, M. (2020). Comparison of microstructural evolution of fuel electrodes in solid oxide fuel cells and electrolysis cells. Journal of Power Sources, 450, [227599]. https://doi.org/10.1016/j.jpowsour.2019.227599

\section{General rights}

Copyright and moral rights for the publications made accessible in the public portal are retained by the authors and/or other copyright owners and it is a condition of accessing publications that users recognise and abide by the legal requirements associated with these rights.

- Users may download and print one copy of any publication from the public portal for the purpose of private study or research.

- You may not further distribute the material or use it for any profit-making activity or commercial gain

- You may freely distribute the URL identifying the publication in the public portal 


\title{
Comparison of microstructural evolution of fuel electrodes
}

\section{in solid oxide fuel cells and electrolysis cells}

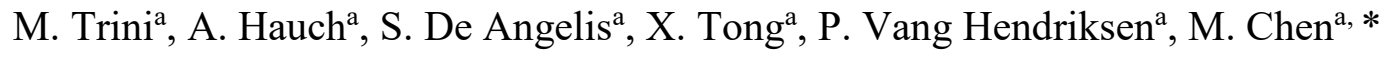 \\ ${ }^{a}$ Department of Energy Conversion and Storage, Technical University of Denmark, \\ Frederiksborgvej 399, 4000 Roskilde, Denmark
}

Corresponding author: Ming Chen

Tel.: + 467757 57; Fax: + 46775858 .

E-mail address: minc@dtu.dk (Ming Chen)

Other authors:

Martina Trini: E-mail address: mtri@dtu.dk;

Anne Hauch: E-mail address: hauc@dtu.dk;

Salvatore De Angelis: E-mail address: $\underline{\text { salvatore.de-angelis@psi.ch; }}$

Xiaofeng Tong: xiatun@ $\mathrm{dtu} . \mathrm{dk}$

Peter Vang Hendriksen: E-mail address: pvhe@dtu.dk.

\begin{abstract}
Solid oxide cells are electrochemical devices used for the conversion of chemical energy to electrical energy (Solid Oxide Fuel Cells-SOFC) and vice versa (Solid Oxide Electrolysis Cells-SOEC). However, long-term performance degradation impedes the widespread commercialization of the technology. To investigate the effects of operation mode on the degradation of $\mathrm{Ni} /$ yttria-stabilized zirconia (YSZ) electrodes, two cells from the same production batch are tested for 1000 hours at $800{ }^{\circ} \mathrm{C}$; one as SOFC and the other as SOEC. The


cells are fed with the same gas composition at the fuel inlet side $\left(\mathrm{p}\left(\mathrm{H}_{2} \mathrm{O}\right) / \mathrm{p}\left(\mathrm{H}_{2}\right)=0.5 / 0.5\right)$ while the direction of the current $\left( \pm 1 \mathrm{~A} \mathrm{~cm}^{-2}\right)$ is reversed. It is found that $\mathrm{Ni}$ coarsening occurs to a similar extent in both operation modes while Ni depletion is only observed in SOEC mode, in the region close to the electrode/electrolyte interface. Here, the $\mathrm{Ni} /(\mathrm{Ni}+\mathrm{Zr}+\mathrm{Y})$ atomic ratio decreases from $\sim 0.49$ before operating the cell to $\sim 0.28$ and the SOEC shows a pronounced decrease in percolating triple phase boundaries (TPBs). The wettability of Ni on YSZ is studied and hypotheses are presented to correlate the phenomena of $\mathrm{Ni}$ coarsening and $\mathrm{Ni}$ depletion with the cell operation mode.

Keywords: solid oxide cell; fuel electrode; Ni-yttria stabilized zirconia; microstructure; coarsening; depletion.

\section{Introduction}

The increased spread of intermittent electricity production over the last decades has introduced the need to overcome mismatches between electrical energy production and consumption. In this context, the development of efficient energy conversion devices such as solid oxide fuel cells (SOFCs) and solid oxide electrolysis cells (SOECs) may play a key role. Solid oxide cells (SOCs) are electrochemical devices able to convert chemical energy to electrical energy when operated as SOFCs and vice versa when operated as SOECs. The same cell can be operated in both modes allowing electricity production or energy storage, depending on the grid demand.

Several years of stable operational lifetime are required to reach the widespread commercialization of the technology $[1-4]$. Several studies have related performance degradation of the cell to the degradation processes occurring in the cell components at the micro-level [5 - 9]. In particular, microstructural changes occurring in the Ni/yttria-stabilized zirconia (Ni/YSZ) electrode during long-term operation have been found to have a strong impact on the performance loss of the cell $[6,10-16]$. Several studies have reported on the 
evolution of the microstructure during SOFC [10, 17 - 23] and SOEC [9, 20 - 25] testing. Main degradation phenomena reported for $\mathrm{Ni} / \mathrm{YSZ}$ electrodes contributing to loss of performance in SOFC mode are: Ni coarsening and re-distribution [10, 17 - 20], sulfur poisoning [26 - 29], carbon deposition [30 - 34], and impurity segregation [35, 36]. For what concerns SOEC operation, several degradation phenomena responsible for the microstructural degradation of the fuel electrodes have been identified; carbon deposition [30, 33, 37], impurity segregation [38], percolation loss due to formation of $\mathrm{ZrO}_{2}$ nanoparticles [39], $\mathrm{Ni}$ coarsening and $\mathrm{Ni}$ depletion [9, 20 - 25].

It is well-known that $\mathrm{Ni}$ coarsening occurs during operation and that it produces a decrease in the number of active electrochemical sites when the cell is operated for extended times both in SOFC [11 - 14] and in SOEC mode [15, 16, 40-42]. Tanasini et al. [10] used Scanning Electron Microscopy (SEM) and galvanostatic tests to relate microstructural changes with performances degradation of an SOFC. The authors concluded that there is no relation between microstructural changes and initial cell activation. However, the experiments highlighted a relation between performance degradation and Ni coarsening [10]. In particular, the more pronounced increase of Ni particles size was observed within the first 200 hours of testing [10]. More recently The et al. [22] observed Ni coarsening and Ni depletion in the innermost region of the active fuel electrode for SOECs tested at $-0.75 \mathrm{~A} \mathrm{~cm}^{-2}$ (6100 hours) and $-1 \mathrm{~A} \mathrm{~cm}^{-2}$ (9000 hours). While a similar degree of Ni coarsening was observed in both cells, the quantification of $\mathrm{Ni}$ concentration in the fuel electrode showed that the phenomenon of $\mathrm{Ni}$ migration away from the electrode/electrolyte interface was much more pronounced for the cell operated at $-1 \mathrm{~A} \mathrm{~cm}^{-2}$. SEM micrographs were used by Fang et al. [24] for the post-test analysis of a SOEC tested for 20000 hours as part of a stack and by Hoerlein et al. [25] for investigating the effect of different operating parameters on 20 single electrolysis cell tests. Ni coarsening and Ni depletion at the interface with the electrolyte were observed in both studies [24, 25]. In 
particular, it was observed that the migration of $\mathrm{Ni}$ away from the electrode/electrolyte interface is affected by current density, cathode overpotential, humidity, and temperature. Mogensen et al. [43] observed Ni depletion in the innermost area of the fuel electrode for SOEC operating temperature lower than $950^{\circ} \mathrm{C}$. The authors hypothesized that the main cause for the Ni migration at testing conditions is the polarization of the electrode [43], as no Ni depletion was observed for cells exposed to same gas and temperature but no current for the same number of hours.

Not many studies have focused on the investigation of the different microstructural degradation occurring in Ni/YSZ electrodes when operating identical cells in SOFC or SOEC mode. Nakajo et al. [44] used 3D Focused Ion Beam - Scanning Electron Microscopy (FIB-SEM) serial sectioning and 3D Energy Dispersive Spectroscopy (EDS) elemental mapping for the post test characterization of cells tested as either SOFC or SOEC. The microstructures of the tested cells were compared with the microstructure of a cell in its pristine state (only reduced not longterm tested). However, different operating conditions (i.e. temperature, gas composition, and current density) were applied during the tests. Furthermore, the microstructure of the SOFC was characterized after 1900 and 4700 hours, while only one characterization was performed for the SOEC after 10700 hours. These differences complicated the comparison, however, the authors detected that Ni coarsens similarly for both operation modes. While in the SOFC the microstructural degradation was observed to be homogeneous throughout the electrode, in SOEC mode Ni depletion was observed to occur in the first $2.5 \mu \mathrm{m}$ close to the electrode/electrolyte interface where also the connectivity of the triple phase boundaries (TPB) was found to be strongly decreased. Hubert et al. [23] investigated the degradation of microstructure and electrochemical performance in cells tested as SOFC and SOEC in the time range 1000-9000 hours in the temperature range $850-950^{\circ} \mathrm{C}$ applying current density of \pm 0.5 $\mathrm{A} \mathrm{cm}^{-2}\left(-0.75 \mathrm{~A} \mathrm{~cm}^{-2}\right.$ was used for one test in SOEC mode). The authors focused on the effect 
of nickel coarsening showing that the sign of the electrode polarization does not affect the coarsening rate. However, a more pronounced performance degradation was observed for the cells operated in SOEC mode. It is noteworthy that no significant Ni depletion was observed for the particular test conditions [23].

In this study, we aim to investigate the main differences in microstructural degradation of $\mathrm{Ni} / \mathrm{YSZ}$ cermets when cells from the same production batch are operated in either SOFC or SOEC mode. The two cells used for the analysis were tested in galvanostatic mode under the same externally set conditions (i.e. $800^{\circ} \mathrm{C}, 50 \% \mathrm{H}_{2} \mathrm{O}-50 \% \mathrm{H}_{2}$ as fuel at the fuel inlet side, and 1000 hours of testing) using a current density of $1 \mathrm{~A} \mathrm{~cm}^{-2}$ for SOFC and $-1 \mathrm{~A} \mathrm{~cm}^{-2}$ for SOEC mode. After the long-term test, the Ni/YSZ electrode microstructure at the inlet side of the two operated cells was compared with a reference cell from the same production batch where $\mathrm{NiO}$ was just reduced to $\mathrm{Ni}$ and the cell was not tested further. The three samples (i.e. reference, SOFC, and SOEC) were characterized using SEM, EDS, and FIB-SEM tomography. We believe that exposing the cells to the same operating conditions and reversing the current between the two operating modes make the aged cells here characterized more directly comparable than in previous studies reported in the literature [23, 44].

\section{Experimental}

\subsection{Electrochemical testing}

Three cells from the same production batch were used for the analysis. They are fuel electrode supported planar type cells, consisting of a thick Ni/YSZ support (300 $\mu \mathrm{m})$, a Ni/YSZ active fuel electrode, a YSZ electrolyte, a $\mathrm{Ce}_{0.9} \mathrm{Gd}_{0.1} \mathrm{O}_{1.95}$ (CGO) interdiffusion barrier layer, and a $\mathrm{La}_{0.6} \mathrm{Sr}_{0.4} \mathrm{Co}_{0.2} \mathrm{Fe}_{0.8} \mathrm{O}_{3-\delta}$ (LSCF)/CGO composite oxygen electrode (Figure 2a). The cells have a footprint of $5.3 \times 5.3 \mathrm{~cm}^{2}$ with an active electrode area of $4.0 \times 4.0 \mathrm{~cm}^{2}$. Further details on the cells are published in [45]. 
Each cell was mounted in a single cell test house. Additional details on the testing procedure can be found elsewhere $[46,47]$. For these experiments, the reduction from $\mathrm{NiO}$ to $\mathrm{Ni}$ in the $\mathrm{Ni} / \mathrm{YSZ}$ electrode was carried at $850^{\circ} \mathrm{C}$. One cell, hereafter labeled "reference", was cooled down to room temperature immediately after reduction (for 2 hours at $850^{\circ} \mathrm{C}$ ). The other two cells were further exposed to long-term galvanostatic durability tests and performance characterization. The SOFC was tested at $800^{\circ} \mathrm{C},+1 \mathrm{~A} \mathrm{~cm}^{-2}$ for $1000 \mathrm{~h}$. The fuel utilization was $\sim 56 \%$ with $241 \mathrm{~h}^{-1} \mathrm{H}_{2} / \mathrm{H}_{2} \mathrm{O}(50 / 50)$ to the $\mathrm{Ni} / \mathrm{YSZ}$ electrode, $501 \mathrm{~h}^{-1} \mathrm{O}_{2}$ to the $\mathrm{LSCF} / \mathrm{CGO}$ electrode. The SOEC was exposed to the same conditions except for the change in current direction, i.e. $-1 \mathrm{~A} \mathrm{~cm}^{-2}$.

Figure 1 shows the electrochemical durability of the cells operated either as SOFC or SOEC. Figure 1a depicts cell voltage as a function of time during the durability test. The initial cell voltages were measured to be 1.246 and $0.790 \mathrm{~V}$ for the SOEC and SOFC, respectively. The cell tested as SOFC shows an overall voltage degradation of $0.8 \% / 1000 \mathrm{~h}$, while a higher degradation rate of $8.3 \% / 1000 \mathrm{~h}$ was observed for the cell tested as SOEC. Figure $1 \mathrm{~b}$ compares the current-voltage (I-V) curves recoreded before and after the durability tests. For SOFC the two I-V curves are almost overlapping, while for SOEC there is an obvious shift of the I-V curve after test, showing a higher overpotential at a certain current density. This result is consistent with the voltage versus time trends during the galvanostatic testing; it confirms the larger degradation of the cell when operated as SOEC. Figure 1c shows the Nyquist plots of electrochemical impedance spectroscopy (EIS) data recorded before and after the durability tests under OCV conditions. For SOFC operation, after the durability test, there is no observable change in the ohmic resistance $\left(\mathrm{R}_{\mathrm{ohm}}\right)$ and only a slight increase in polarization resistance $\left(\mathrm{R}_{\mathrm{p}}\right)$. By contrast, after the aging under SOEC conditions there is a slight increase in $\mathrm{R}_{\mathrm{ohm}}$ and a clear increase in $\mathrm{R}_{\mathrm{p}}$, much larger than observed for SOFC test. In order to clarify the different contributions to the increase of $\mathrm{R}_{\mathrm{p}}$, the EIS data shown in Figure 1c were analyzed 
considering the distribution of relaxation times (DRT). In the DRT plots shown in Figure 1d, each peak represents an electrode process and the integral area under each peak represents the resistance of the process. On the basis of previously reported analyses [48 - 50], the peak centered at $\sim 10 \mathrm{kHz}$ (marked by dashed circle) is likely associated with the electrochemical process at the TPBs of the Ni/YSZ fuel electrode, and the peak centered at $\sim 50 \mathrm{~Hz}$ (marked by solid circle) is most likely associated with the electrochemical process at the TPBs of the LSCF/CGO electrode as well an impedance contribution attributed to gas diffusion in the same frequency range. The peaks centered at $\sim 10 \mathrm{kHz}$ show a significant increase after both SOFC and SOEC tests, while the increase for SOEC is much larger than that for SOFC. Furthermore, the peaks centered at $\sim 50 \mathrm{~Hz}$ only have a slight increase after both SOFC and SOEC tests. These EIS results suggest that the performance degradation both in SOFC and SOEC mode originates mainly from the Ni/YSZ electrode. Furthermore, in SOEC mode, the degradation of the Ni/YSZ electrode is much more severe. A more detailed electrochemical characterization will be published elsewhere. 

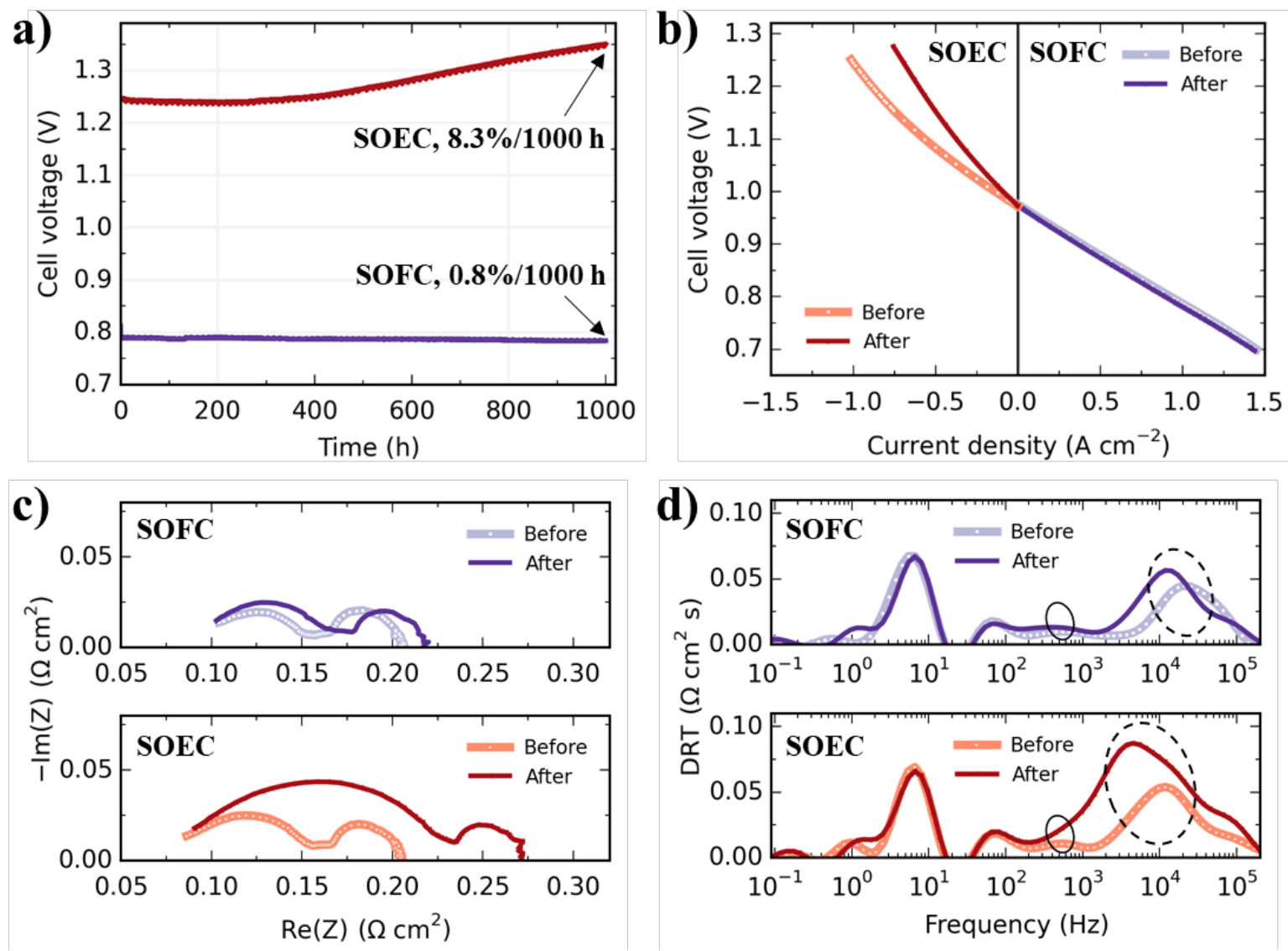

Figure 1: Comparison of electrochemical durability for SOFC and SOEC operation. a) Voltage profile as a function of time. b) I-V curves recorded before and after the durability tests. c) Nyquist plots of impedance data recorded before and after the $1000 \mathrm{~h}$ durability tests under OCV conditions. d) Corresponding DRT plots for the impedance data shown in Figure 1c. Durability tests were performed at $800{ }^{\circ} \mathrm{C}$ under constant current densities of $+/-1.00 \mathrm{~A} \mathrm{~cm}^{-2}$ with $241 \mathrm{~h}^{-1} \mathrm{H}_{2} / \mathrm{H}_{2} \mathrm{O}(50 / 50)$ to the $\mathrm{Ni} / \mathrm{YSZ}$ electrode and $501 \mathrm{~h}^{-1} \mathrm{O}_{2}$ to the $\mathrm{LSCF} / \mathrm{CGO}$ electrode.

\subsection{SEM sample preparation}

After testing, three cross-sections were selected for microstructural analysis: one for the reference cell, one for the SOFC and one for the SOEC. The location for the microstructural characterization was chosen at the inlet side of the cells to ensure that the cells were exposed to the same gas composition, i.e. the main difference during the aging is the direction of the current (this will of course affect the sign of the polarization and the direction of the introduced gas-phase gradient). The three samples were embedded in epoxy resin, ground and polished for the SEM analysis and FIB-SEM tomography. 
a)

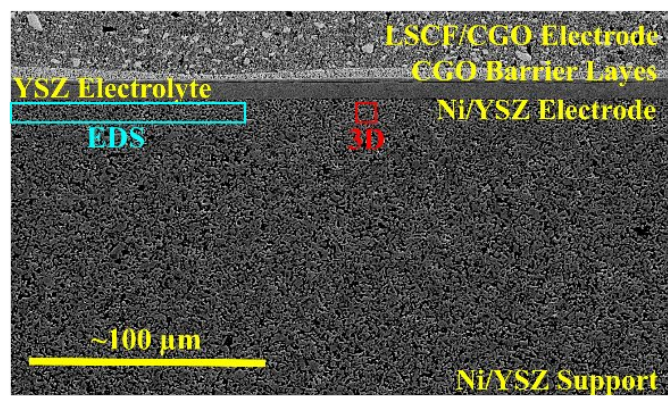

c)

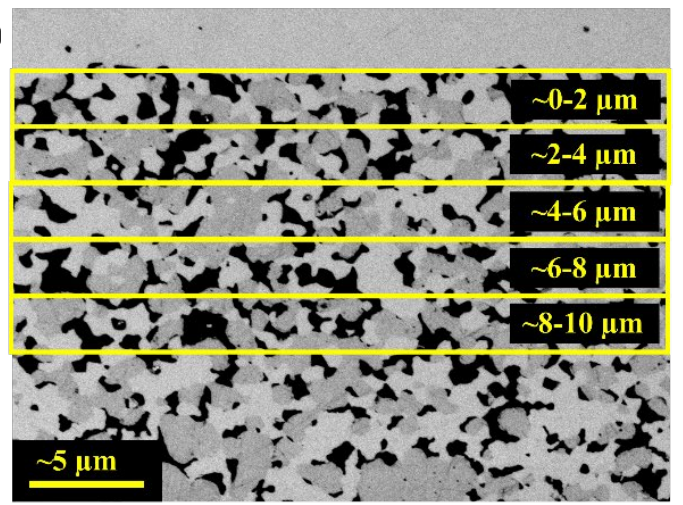

b)

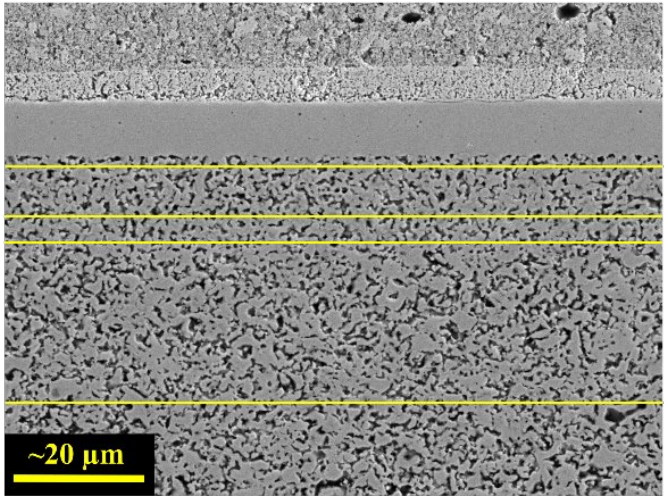

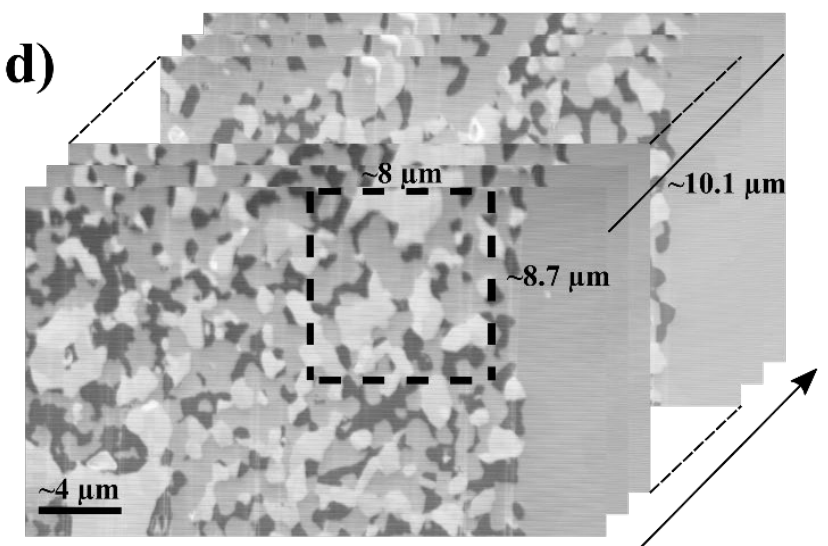

FIB Milling Front Direction

Figure 2: Different SEM micrographs of the reference cell cross-section illustrating the data acquisition procedure. a) Overview image of the layers composing the cell with highlights on the regions used for EDS analysis (light blue rectangle) and for the 3D reconstruction (red rectangle). b) Image of one of the locations used for the acquisition of EDS line scan. The locations used for the line scan are represented with yellow horizontal lines. c) Image acquired with EsB detector and used for the porosity quantification. The yellow rectangles indicate the sub-regions used for the analysis. d) FIB-SEM cross-sections recorded with the Inlens detector while milling the sample along the milling front direction.

\subsection{Energy dispersive X-ray spectroscopy - EDS}

The EDS analysis was performed with a field emission gun (FEG) scanning electron microscope (Zeiss Merlin) equipped with an X-ray detector (Quantax X-ray detector - Bruker). The region characterized by the EDS analysis is highlighted in Figure 2a with a light blue rectangle. Figure $2 \mathrm{~b}$ illustrates one of the SEM images $(\sim 100 \mu \mathrm{m}$ width micrograph) of the reference cell used for EDS line scans. An acceleration voltage of $15 \mathrm{kV}$ was used giving an interaction volume of approximately $\sim 600 \mathrm{~nm}^{3}$. Four line scans were recorded for each image at different distances from the electrode/electrolyte interface: $\sim 2,8,12$, and $30 \mu \mathrm{m}$ 
corresponding to "inner" part of active fuel electrode, "outer" part of active fuel electrode, “inner" part of electrode support layer and "support" layer, respectively. A spectrum was obtained for each of the 100 points along each line. The yellow horizontal lines in Figure $2 \mathrm{~b}$ are placed in correspondence with the lines scan recorded on each image. The Quantax Esprit 1.9 Bruker software was used with ZAF correction and the acquisition time for each line was 10 minutes. Figure 3 illustrates the quality of the EDS spectra recorded at each of the 100 points scanned along each line. Two images were analyzed for each sample covering an electrode/electrolyte length of $\sim 200 \mu \mathrm{m}$. The $\mathrm{Ni} /(\mathrm{Ni}+\mathrm{Zr}+\mathrm{Y})$ atomic ratio was computed for each point scanned along the lines. The results were then averaged and the average was considered representative for the location at a specific distance $(2,8,12$, and $30 \mu \mathrm{m}$, respectively) from the electrode/electrolyte interface.

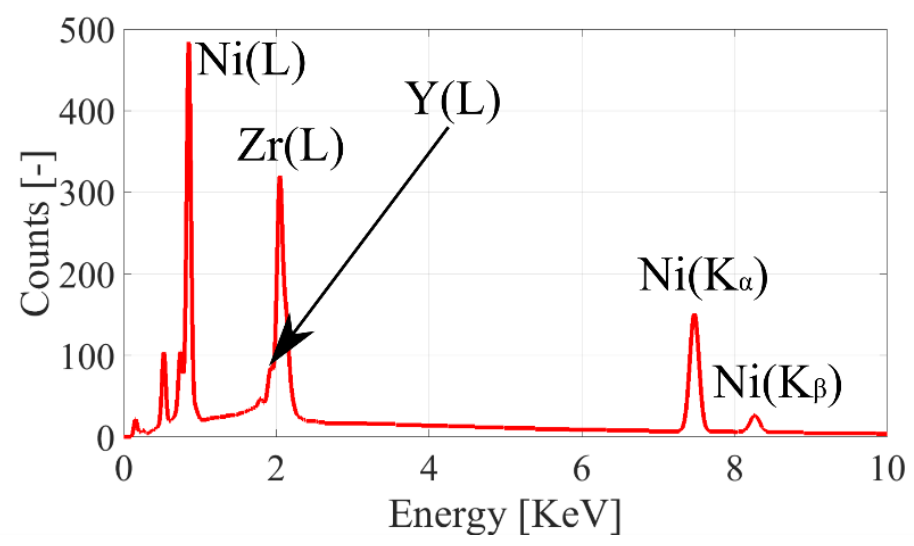

Figure 3: EDS spectrum of one of the 100 points recorded for the line scan obtained for the reference cell at a distance of 8 $\mu \mathrm{m}$ from the electrode/electrolyte interface.

\section{$\underline{2.4 \text { SEM analysis }}$}

Low voltage SEM micrographs as the one illustrated in Figure $2 \mathrm{c}$ were recorded for quantifying the porosity in the active fuel electrode. The FEG Zeiss Merlin SEM equipped with an Energy selective Backscattered (EsB) detector was used for recording low voltage and high current images ( $2.5 \mathrm{kV}$ and $18 \mathrm{nA}$, respectively). The working distance was $\sim 3.9 \mathrm{~mm}$ and the filtering 
grid was set to $1.5 \mathrm{kV}$. More details on the microscope setup are published elsewhere [51]. The $10 \mu \mathrm{m}$ thick active electrode was divided into five regions of $\sim 2 \times 28 \mu \mathrm{m}^{2}$ area each (yellow rectangles in Figure 2c) to quantify the porosity variation in the direction perpendicular to the electrode/electrolyte interface. The statistical power analysis was used to determine the number of images to analyze [52]. To keep the number of images low while still being able to detect nickel depletion in the innermost area of the electrode, 30 images were acquired and analyzed (details on the statistical power analysis are reported in Figure S1 in the supplementary materials). An overall area of approximately $1680 \mu \mathrm{m}^{2}$ was covered for each of the five regions analyzed. The average pore fraction obtained from the 30 images for each region was used as the representative value of the specific region. The SEM images used for the qualitative analysis of Ni network percolation were obtained with the FEG Zeiss Merlin SEM using the Inlens detector at $1 \mathrm{kV}$. The images recorded with the Inlens detector using the microscope low voltage setup allow to clearly detect the percolating Ni network which appears much brighter than the other phases. More details on this imaging technique can be found elsewhere [53].

\subsection{FIB-SEM tomography and 3D characterization}

The FIB-SEM tomograms used for three-dimensional reconstructions were acquired with a Zeiss XB1540 Crossbeam microscope. Figure 2d illustrates a few raw images acquired with the Inlens detector during the FIB-SEM serial sectioning and the direction of the milling front. The three-dimensional reconstructions were performed on the representative area highlighted by the black rectangle in Figure $2 \mathrm{~d}$. The microstructural parameters computed on the 3D reconstructions were used as a complementary dataset to the results obtained from the analysis of EDS and SEM micrographs (the data are more detailed but less representative due to the limited volume). The area selected for the three-dimensional characterization starts approximately $1 \mu \mathrm{m}$ away from the electrode/electrolyte interface and ends $\sim 1 \mu \mathrm{m}$ before reaching the interface between the active fuel electrode and the support layer. To analyze the 
same volume for the three samples, the maximum size of the sub-volume extractable from the data sets was $\sim 8.7 \times 8.0 \times 10.1 \mu \mathrm{m}^{3}$. Slightly different microscope set-ups were used for the three samples resulting in different voxel sizes: $25 \times 25 \times 46.8 \mathrm{~nm}^{3}$ for the reference cell, $25 \mathrm{x}$ $25 \times 35.0 \mathrm{~nm}^{3}$ for the SOFC and $25 \times 25 \times 42.3 \mathrm{~nm}^{3}$ for the SOEC tested cell. The dimensions of the sub-volumes used for the $3 \mathrm{D}$ characterization were $374 \times 321 \times 216$ pixels, $374 \times 321 \times$ 289 pixels, and $374 \times 321 \times 239$ pixels for the reference, SOFC, and SOEC, respectively. Two images (from the Inlens detector and from the SE2 detector) were simultaneously acquired and used for post-processing and segmentation as described in [54]. More details on the FIB-SEM serial sectioning and the image's post-processing can be found in $[15,54]$.

Microstructural parameters were computed on the segmented volumes to compare the Ni/YSZ microstructures after operation in SOFC and SOEC mode with the one of the reference cell. The phase fraction of each volume was calculated by dividing the volume occupied by one of the three phases (i.e. Ni, YSZ, and pores) by the overall volume analyzed. The particles size was computed using the continuous particle size distribution (PSD) approach $[15,54,55]$. For computing the continuous PSD, a distance map is calculated for each phase to find the center of the spheres used for fitting the network without overlapping with other phases. The radius of each sphere is dilated to cover all the volume of the analyzed phase. For each spheres radii, the volume occupied is measured and the continuous PSD is given by the histogram of the volumes covered. Additionally, total and percolating TPB are computed [21, 54]. In a TPB site the three phases (Ni, YSZ, and pores) coexist. From the segmented volumes, each phase is triangulated and the single edge of a triangle that separates both $\mathrm{Ni} /$ pore, $\mathrm{Ni} / \mathrm{YSZ}$, and YSZ/pore at the same time is considered as a TPB segment. The total TPB density is the total length of those segments divided by the analyzed volume. The percolating TPB density is obtained by summing up the TPB segments being connected through all three phases to each side of the analyzed volume. 


\section{Results}

\subsection{SEM images}

Figure 4 shows SEM micrographs recorded with the EsB detector for porosity quantification (Figure 4a, 4b, and 4c) and low voltage images obtained with the Inlens detector, qualitatively showing Ni percolation (Figure 4d, 4e, and 4f). In Figure 4a - 4c porosity is black, nickel is dark gray and the YSZ is light gray while in Figure $4 d-4 f$ the white phase is the percolating $\mathrm{Ni}$, non-percolating nickel and YSZ are gray, and porosity is black. The SEM micrographs in Figure 4 illustrate the Ni coarsening upon aging. Comparing the microstructure of the tested cells (Figure 4b, 4c, 4e, and 4f) with the reference (Figure $4 \mathrm{a}$ and $4 \mathrm{~d}$ ) it is evident that the Ni networks tend to coalesce during operation, resulting in bigger clusters after 1000 hours of operation for both SOFC and SOEC. In addition to the Ni coarsening, the cell operated as SOEC shows an increase in pore fraction and pore size close to the electrode/electrolyte interface (Figure 4c). The YSZ network appears to be unaffected by the applied test conditions $[10,14,15]$. Therefore, assuming an invariant YSZ scaffold, an increase in pore fraction must correspond to a decrease of $\mathrm{Ni}$ content in the investigated region.

The percolating $\mathrm{Ni}$ is illustrated for the three samples in Figure 4d (Reference), Figure 4e (SOFC), and Figure $4 \mathrm{f}$ (SOEC). Clearly, the fraction of percolating Ni in the innermost part of the fuel electrode in SOEC mode is decreased compared to SOFC and reference. The red dashed lines in Figure $4 \mathrm{~d}-4 \mathrm{f}$ highlight the region where percolating Ni decreases more in the SOEC (Figure 4f) than in the other two cases. In contrast, the SOFC does not show a visible decrease in the fraction of percolating Ni (Figure 4e). 

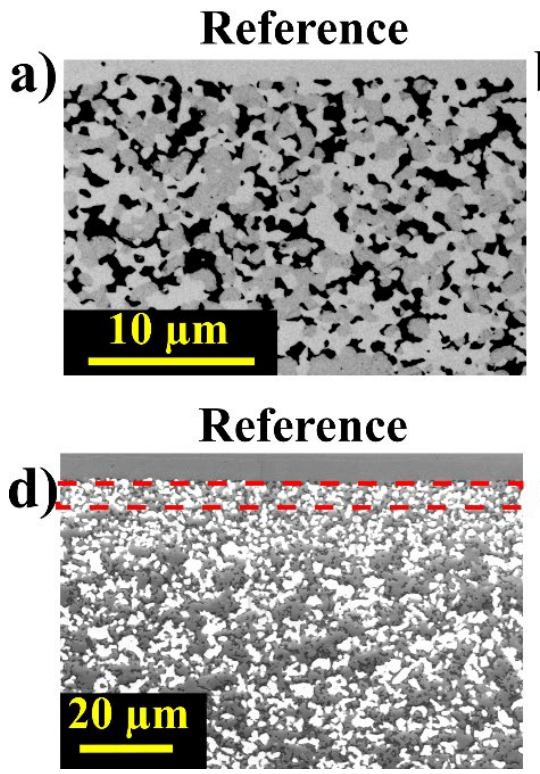

SOFC

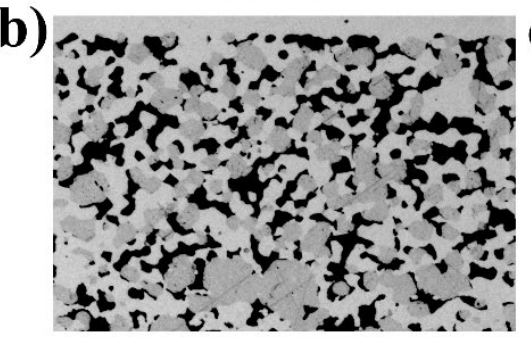

SOFC

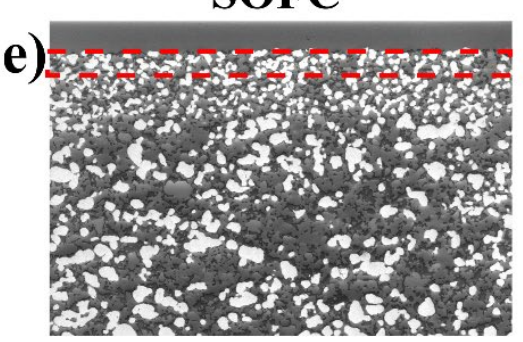

SOEC

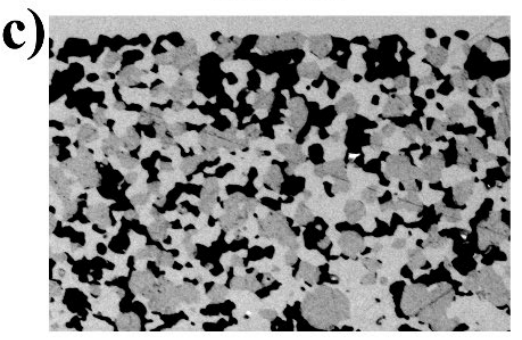

SOEC

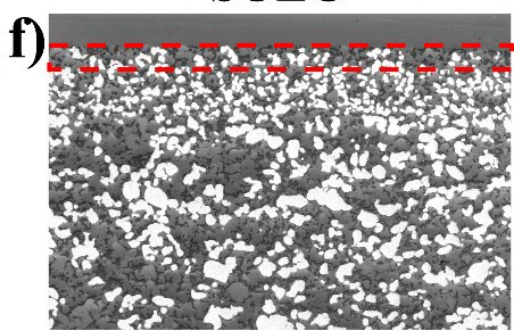

Figure 4: SEM images of the three samples; reference a) and d), SOFC b) and e), and SOEC c) and f). In the low voltage ESB images a)-c) porosity is black, YSZ is light gray, and Ni is dark gray. In the low voltage images recorded with the Inlens detector d)-f) porosity is black, YSZ and non-percolating Ni are gray and the percolating Ni is white. The dashed lines in d)f) indicate the area where the decrease of percolating Ni is more visible.

\section{$\underline{3.2 \mathrm{Ni} \text { depletion - EDS and SEM micrographs }}$}

Figure 5 summarizes the results for the Ni distribution in the active fuel electrode and in the support, quantified based on EDS data and SEM micrographs. Figure 5a shows a significant Ni depletion in the SOEC at a distance of $2 \mu \mathrm{m}$ from the electrode/electrolyte interface, the ratio $(\mathrm{Ni} /(\mathrm{Ni}+\mathrm{Zr}+\mathrm{Y}))$ decreases from $\sim 0.49$ for the reference sample to $\sim 0.28$ for the cell aged in SOEC mode. Based on data from cell manufacturing, the ratio in the reference cell is expected to be $\sim 0.48$ (gray dashed line in Figure 5a), very well in line with experimental findings. Noteworthy, the depletion was not observed for the SOFC showing $\mathrm{Ni} /(\mathrm{Ni}+\mathrm{Zr}+\mathrm{Y})$ $\approx 0.46$. Figure 5 a shows changes in the Ni ratio moving from the electrode/electrolyte interface towards the support layer. The ratio was measured to be between $\sim 0.45$ and $\sim 0.55$ for all the samples at the distance of 8 and $12 \mu \mathrm{m}$ from the electrode/electrolyte interface. The line scan recorded in the support layer closest to the active electrode $(\sim 12 \mu \mathrm{m}$ from the 
electrode/electrolyte interface) shows a slight increase of Ni content for the SOEC, however, this increase is within the error of the measurements. Finally, the line scan recorded in the innermost area of the support layer $(\sim 30 \mu \mathrm{m}$ from the electrode/electrolyte interface) shows similar $\mathrm{Ni} /(\mathrm{Ni}+\mathrm{Zr}+\mathrm{Y})$ ratio values for both $\mathrm{SOFC}$ and $\mathrm{SOEC}(\sim 0.51)$, and reference cell $(\sim$ 0.47). Hence, in summary, in SOEC mode Ni is depleted at the electrode/electrolyte interface and seems slightly enriched at the electrode/support interface, while in SOFC mode such phenomenon is not observed.

Figure $5 \mathrm{~b}$ shows the average pore fraction obtained from the analysis of 30 SEM images. Five points are obtained for each sample, each point corresponds to the estimated porosity of one of the areas in the yellow rectangles in Figure 2c. The values in Figure $5 \mathrm{~b}$ are interpolated with a cubic spline (dashed lines) for each sample. It is a clear observation that the pore fraction in the reference cell and in the SOFC varies less than in the SOEC. A pore fraction fluctuation in the range $\sim 24-28 \%$ is observed for the reference cell (green lines in Figure $4 \mathrm{~b}$ ) while the variation for the SOFC is between 23 and $28 \%$. When the cell is operated in SOEC mode (red line in Figure $4 b$ ), the pore fraction decreases form $\sim 33 \%$ to $\sim 22 \%$ by moving from the electrode/electrolyte interface towards the support layer. It is worth noticing that the pore phase of the SOEC shows high porosity until $\sim 4 \mu \mathrm{m}$ from the electrode/electrolyte interface before it assumes a lower value than in the reference. The theoretical minimum limit for the pore fraction of a $\mathrm{Ni} / \mathrm{YSZ}$ electrode with a Ni/YSZ volume ratio of 40/60 will be $21.8 \%$ (gray dashed line in Figure $5 b$ ) based on fully dense structure prior to reduction ie. porosity only originating from the reduction of $\mathrm{NiO}$ to $\mathrm{Ni}$. In SOEC mode, the porosity variation is consistent with the observed $\mathrm{Ni}$ variation; $\mathrm{Ni}$ is depleted at the electrolyte/electrode interface (increased pore fraction at $1 \mu \mathrm{m}$ ) and enriched between 8 and $12 \mu \mathrm{m}$ from the interface, which corresponds well to the reduced pore fraction in the region $5-10 \mu \mathrm{m}$ from the interface. 

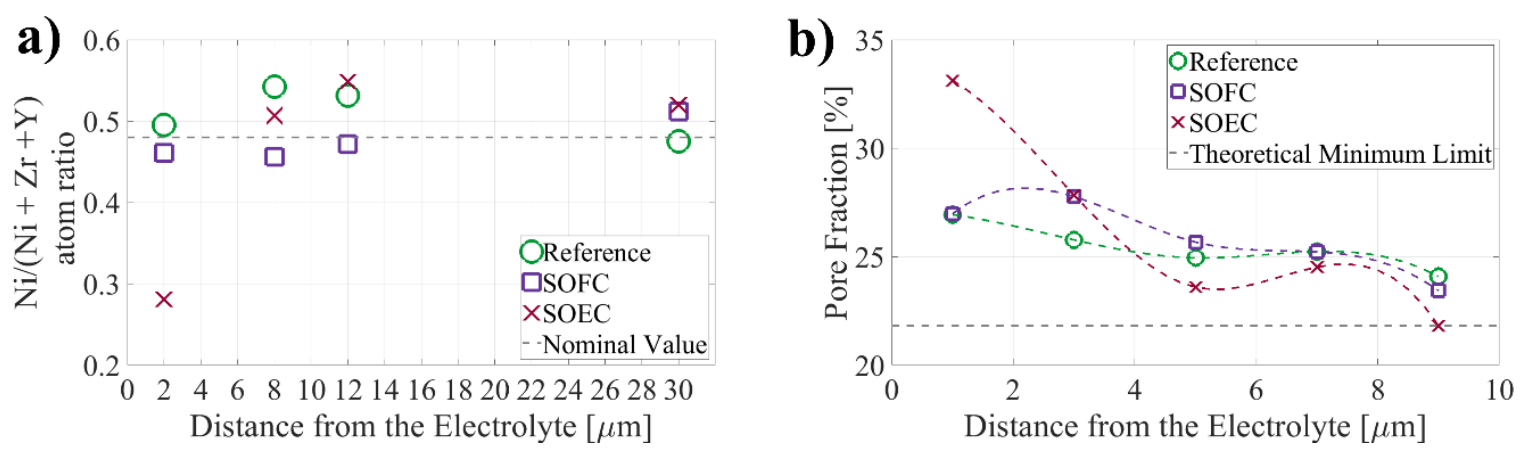

Figure 5: EDS results a) and porosity quantification performed on SEM images b) for the three samples analyzed. The nominal value for the Ni ratio in Figure 5a $(0.48)$ is calculated based on cell manufacturing data. The theoretical minimum limit for the pore fraction shown in Figure $5 \mathrm{~b}(21.8 \%)$ is calculated based on porosity only originating from the reduction of $\mathrm{NiO}$ to $\mathrm{Ni}$ for a Ni/YSZ electrode with a Ni/YSZ volume ratio of $40 / 60$.

\section{$\underline{3.33 \mathrm{D} \text { reconstructions and microstructural parameters }}$}

Figure 6 shows the three-dimensional reconstructions of three sub-volumes $\left(\sim 8 \times 8 \times 8 \mu \mathrm{m}^{3}\right.$ including part of the electrolyte) of the FIB-SEM datasets for the reference cell, the SOFC, and the SOEC. In Figure 6, the Ni phase is colored in red, YSZ in gray and the pores are transparent. Microstructural parameters are computed on sub-volumes extracted from the innermost part of the electrode, to include only the active electrode in the calculations. Figure 6 shows a more pronounced microstructural degradation of the SOEC by simple visual inspection of the threedimensional renderings. It is worth noting that whereas more detailed data can be extracted from the 3D reconstructions than the SEM/EDS cross sections discussed in section 3.1 and 3.2, the data are less representative due to the limited volume size. 

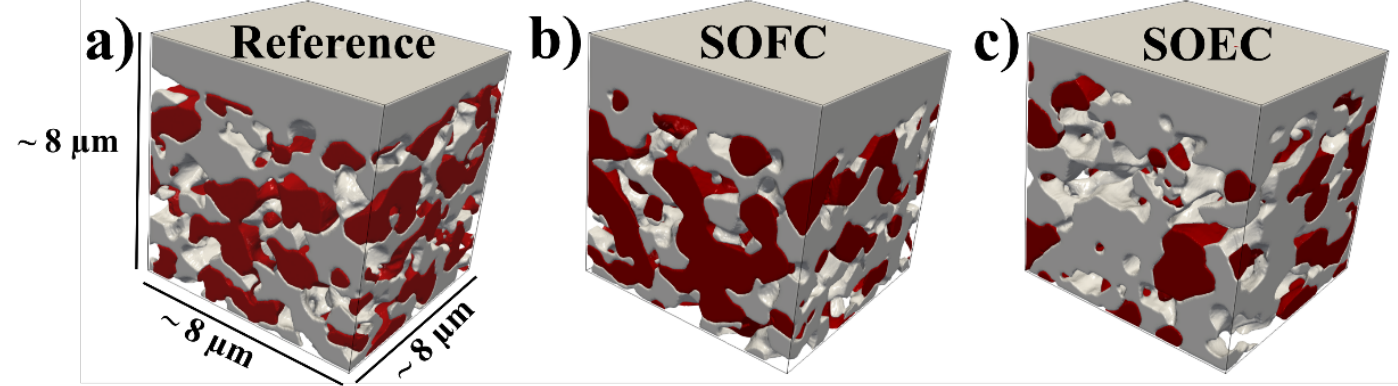

Figure 6: Three-dimensional renderings of sub-volumes extracted from the FIB-SEM datasets for the reference cell a), the SOFC $b$ ), and the SOEC c). Ni is red, YSZ is gray, and pores are transparent.

Figure 7 shows the continuous PSD of the analyzed cells for each of the three phases (i.e. Ni, YSZ, and pore). For the Ni phase (Figure 7a), the peak of the continuous PSD curve shifts from $\sim 400 \mathrm{~nm}$ observed on the reference cell to approximately $\sim 600 \mathrm{~nm}$ after SOFC and SOEC operation. Interestingly, the continuous PSD distribution of the pores and the YSZ shows different trends over time for the two cells tested. Figure $7 \mathrm{~b}$ shows similar pore phase PSD for the SOFC and the reference with a peak at approximately $300 \mathrm{~nm}$. The peak for the SOEC is observed at $\sim 350 \mathrm{~nm}$ and is broader than the ones for the reference cell and the SOFC. An unexpected trend for the PSD of YSZ is found for the SOFC (Figure 7c) showing a more pronounced peak for a particle radius of $\sim 300 \mathrm{~nm}$. 

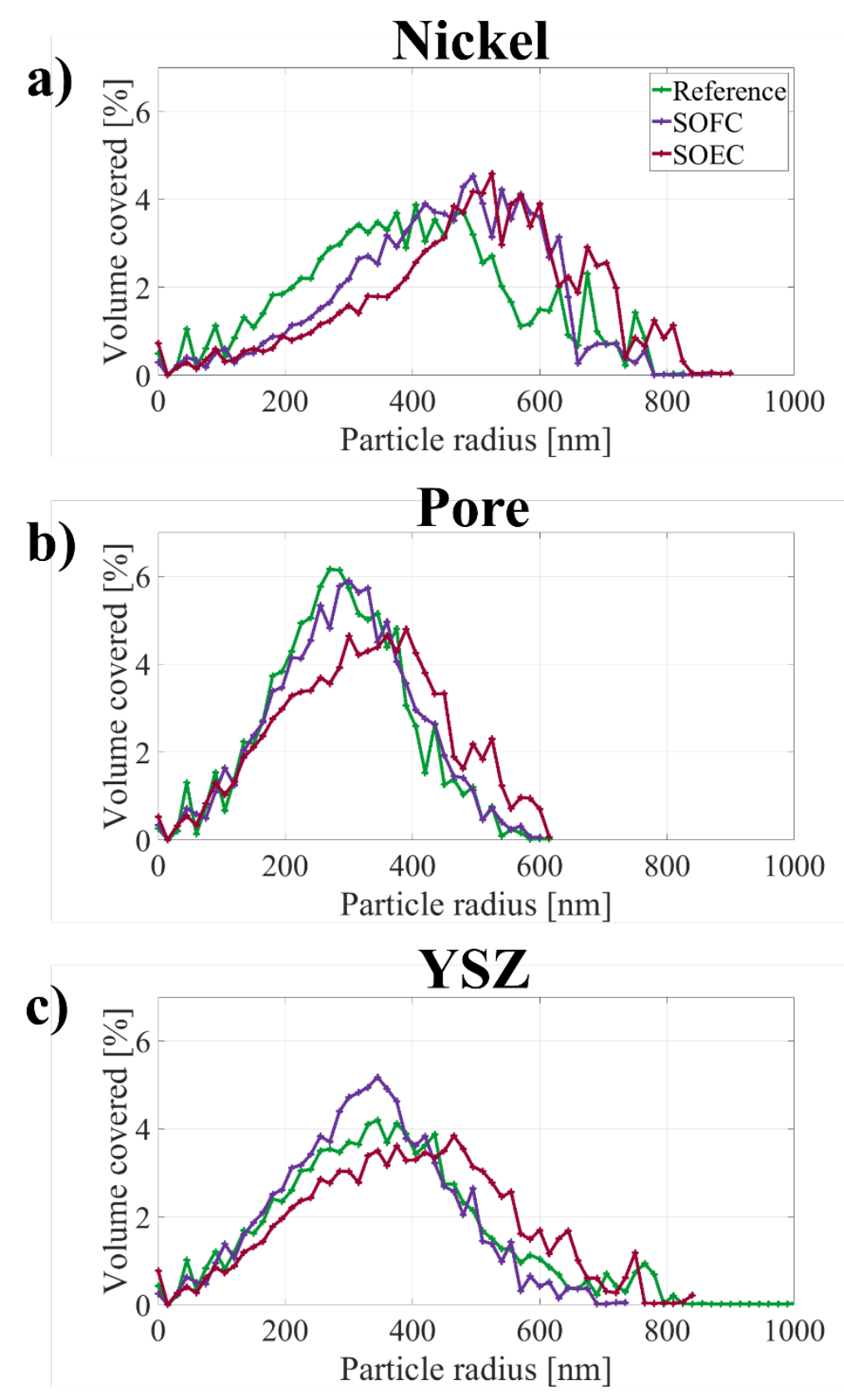

Figure 7: Continuous PSD computed for each phase (Ni, pore, and YSZ) on the three samples analyzed (reference cell, SOFC, and SOEC).

Table 1 summarizes the microstructural parameters computed on the three volumes. Errors in image post-processing and segmentation together with the limited volume size result in large uncertainty on the computation of the phase fractions $( \pm 2.50$, see Table 1$)$. Finite sampling volume leads to the unexpected differences in the YSZ phase fraction which is known to be stable during the test. The apparent variations in the YSZ phase fraction illustrate the level of accuracy of this measurement. $41 \pm 2.50 \%$ of the analyzed microstructure of the reference cell 
was occupied by YSZ while $39 \pm 2.50 \%$ and $43 \pm 2.50 \%$ was obtained for the SOFC and SOEC, respectively. The fact that the phase fractions (Table 1) are computed over the entire three-dimensional volumes prevents the detection of local changes in the different regions of the active fuel electrode (Figure 2c) as was observed in the EDS data and the 2D SEM micrographs (Figure 5). The total and percolating TPB length show a much more pronounced decrease after the SOEC operation compared to the SOFC operation tested cell. Indeed, starting from a TPB density of $2.44 \mu \mathrm{m} \mu \mathrm{m}^{-3}$ for the reference cell, $2.40 \mu \mathrm{m} \mu \mathrm{m}^{-3}$ is computed on the SOFC volume and only $1.47 \mu \mathrm{m} \mu \mathrm{m}^{-3}$ on the SOEC. Similarly, the percolating TPB length decreases from $2.19 \mu \mathrm{m} \mu \mathrm{m}^{-3}$ on the reference cell to $2.09 \mu \mathrm{m} \mu \mathrm{m}^{-3}$ and $1.36 \mu \mathrm{m} \mu \mathrm{m}^{-3}$ on the SOFC and SOEC, respectively.

The results of interface and surface areas are further summarized in Table 1. The Ni surface area decreases after the operation in both SOFC- and SOEC-mode. Similarly, a decrease of $\mathrm{Ni} /$ pore and Ni/YSZ interface areas is observed when comparing the reference cell with both tested cells. On the other hand, the surface area of the pores remains unchanged after the SOFC test while a decrease is observed after the SOEC test. More pronounced changes in surface and interface areas are recorded when the cell is operated as SOEC. In particular, the surface area of Ni decreases from $1.46 \mu \mathrm{m}^{2} \mu \mathrm{m}^{-3}$ for the reference cell to $1.33 \mu \mathrm{m}^{2} \mu \mathrm{m}^{-3}$ and $1.17 \mu \mathrm{m}^{2} \mu \mathrm{m}^{-}$ ${ }^{3}$ for SOFC and SOEC, respectively. Likewise, the Ni/pore and Ni/YSZ interface areas are computed to be $0.61 \mu \mathrm{m}^{2} \mu \mathrm{m}^{-3}$ and $0.85 \mu \mathrm{m}^{2} \mu \mathrm{m}^{-3}$ for the reference cell, respectively, while only $0.40 \mu \mathrm{m}^{2} \mu \mathrm{m}^{-3}$ and $0.77 \mu \mathrm{m}^{2} \mu \mathrm{m}^{-3}$ for the SOEC, respectively. Also, small changes in the YSZ surface area are observed and will be discussed further in the Discussion section. 
Table 1: Microstructural parameters calculated on the three-dimensional reconstructions of the three samples analyzed

\begin{tabular}{cccc} 
& Reference & SOFC & SOEC \\
Ni Phase Fraction [\%] & $29 \pm 2.50$ & $30 \pm 2.50$ & $27 \pm 2.50$ \\
Pore Phase Fraction [\%] & $30 \pm 2.50$ & $31 \pm 2.50$ & $31 \pm 2.50$ \\
YSZ Phase Fraction [\%] & $41 \pm 2.50$ & $39 \pm 2.50$ & $43 \pm 2.50$ \\
Total TPB Length $\left[\mu \mathrm{m} \mu \mathrm{m}^{-3}\right]$ & $2.44 \pm 0.10$ & $2.40 \pm 0.10$ & $1.47 \pm 0.10$ \\
Percolating TPB Length $\left[\mu \mathrm{m}^{-3} \mathrm{~m}^{-3}\right]$ & $2.19 \pm 0.15$ & $2.09 \pm 0.15$ & $1.36 \pm 0.15$ \\
Nickel Surface Area $\left[\mu \mathrm{m}^{2} \mu \mathrm{m}^{-3}\right]$ & $1.46 \pm 0.05$ & $1.33 \pm 0.05$ & $1.17 \pm 0.05$ \\
Pore Surface Area $\left[\mu \mathrm{m}^{2} \mu \mathrm{m}^{-3}\right]$ & $1.83 \pm 0.05$ & $1.84 \pm 0.05$ & $1.52 \pm 0.05$ \\
YSZ Surface Area $\left[\mu \mathrm{m}^{2} \mu \mathrm{m}^{-3}\right]$ & $2.07 \pm 0.03$ & $2.13 \pm 0.03$ & $1.89 \pm 0.03$ \\
Ni/Pore Interface Area $\left[\mu \mathrm{m}^{2} \mu \mathrm{m}^{-3}\right]$ & $0.61 \pm 0.05$ & $0.52 \pm 0.05$ & $0.40 \pm 0.05$ \\
Ni/YSZ Interface Area $\left[\mu \mathrm{m}^{2} \mu \mathrm{m}^{-3}\right]$ & $0.85 \pm 0.05$ & $0.81 \pm 0.05$ & $0.77 \pm 0.05$ \\
Pore/YSZ Interface Area $\left[\mu \mathrm{m}^{2} \mu \mathrm{m}^{-3}\right]$ & $1.22 \pm 0.05$ & $1.32 \pm 0.05$ & $1.12 \pm 0.05$ \\
\hline
\end{tabular}

\section{Discussion}

\subsection{Ni coarsening}

From the qualitative illustration of Ni coarsening (Figure 4) and the PSD quantification (Figure 7), it is clear that Ni coarsens to a similar extent when operating the cell as SOFC or SOEC. Ni coarsening does not appear to be affected by the direction of the current in the cell in line with the finding of Nakajo et al. [44] and Hubert et al. [20] and such coarsening was observed to take place even at OCV (no current) as reported also by Mogensen et al. [43]. The PSD was computed also for pores and YSZ. While the porosity PSD of the SOFC was similar to the one of the reference cell, the PSD of the SOEC shifted towards higher values of pore radii (Figure 
7b). In fact, the migration of $\mathrm{Ni}$ away from the electrode/electrolyte interface leaves empty areas that increase the overall porosity (Figure 4c) and its characteristic size (Figure 7b). For what concerns the YSZ, the PSD of the SOEC shows a similar trend to the reference cell while the SOFC curve has a peak around $350 \mathrm{~nm}$ not observed for the other two samples. This fact is a consequence of the local nature of the FIB-SEM characterization which here was limited to small volumes. Therefore, the FIB-SEM results are affected by errors due to the lack of representative volumes. In fact, the EDS analysis shows that the $\mathrm{Zr}$ content in the three samples varies over segments of length of $8 \mu \mathrm{m}$ (edge length of the FIB-SEM volume) taken along the $100 \mu \mathrm{m}$ line scan (Figure S2 in the supplementary materials) while the $\mathrm{Zr}$ content computed over the entire $100 \mu \mathrm{m}$ line does not change in the three samples analyzed. This illustrates that with a segment of $8 \mu \mathrm{m}$ one is at a rather "short" length scale considering the characteristic length scale of compositional variations introduced by imperfections in the mixing and shaping process applied in the cell manufacture.

\subsection{Ni depletion as a major cause of SOEC degradation}

From the EDS analysis, we observe a pronounced decrease of the $\mathrm{Ni} /(\mathrm{Ni}+\mathrm{Zr}+\mathrm{Y})$ atomic ratio for the SOEC at a distance of $2 \mu \mathrm{m}$ from the electrode/electrolyte interface. Such a decrease is not observed for the SOFC (Figure 4a). This loss of Ni in the region close to the SOEC electrode/electrolyte interface reduces the electronic conductivity and the number of active sites for electrochemical reaction, as confirmed by FIB-SEM results, which show the decrease of both total and percolating TPB density. These microstructural changes are responsible for the degradation of the electrical performance of the SOEC. We suggest that the more pronounced voltage deterioration observed in the SOEC mode compared to the SOFC (Figure 1) is mainly ascribed to the Ni depletion in the innermost area of the fuel electrode. In fact, while Ni coarsening seems to occur to a similar extent showing similar Ni PSD for both tested 
cells (Figure 7), the more pronounced decrease of TPB observed for the SOEC indicates that Ni depletion plays the primary role to the increase of the overpotential.

The percolating TPB density is a good microstructural parameter that can be correlated with the electrochemical performance of the cell. The fact that the decrease of percolating TPBs for the SOEC mode is beyond what would be expected by simple Ni coarsening as observed for the SOFC suggests that the electrode polarization itself (and its sign) is the triggering factor for the microstructural changes that leads to the loss of cell performance. A reduction of TPB length density of tested Ni/YSZ electrodes has previously been observed for both SOFC [12, $20,56,57]$ and SOEC $[15,20,51]$ operation.

Previous studies have reported that Ni coarsening is the main microstructural degradation process occurring at low current densities $\left(-1 \mathrm{~A} \mathrm{~cm}^{-2}\right)[39,45,58]$. From our observations, Ni depletion in the innermost part of the active SOEC electrode is an even more severe degradation process for the SOEC Ni/YSZ electrode microstructure, affecting the cell electrochemical performance. This is in line with results reported in references [22-24, 47]. However, in the area of the support layer closer to the electrode, the $\mathrm{Ni} /(\mathrm{Ni}+\mathrm{Zr}+\mathrm{Y})$ ratio of the $\mathrm{SOEC}$ is higher than in the reference, in line with the experimental observations of Sun et al. [47]. By moving further outwards into the support layer at $\sim 30 \mu \mathrm{m}$ from the electrode/electrolyte interface, both the SOFC and the SOEC show a slight enrichment in Ni compared with the reference.

The small enrichment observed in the $\mathrm{Ni} /(\mathrm{Ni}+\mathrm{Zr}+\mathrm{Y})$ ratio for the SOEC hints that, in SOEC mode, Ni migrates from the electrode/electrolyte interface towards the support. In SOFC mode, the trend for Ni migration is not that clear. It is worth noting that the phenomenon of $\mathrm{Ni}$ migration is not described by the three-dimensional characterization presented here and in [20]. 
Indeed, each phase fractions value reported in Table 1 represents an average computed over the entire analyzed volume.

The gas composition also varies along the electrode/electrolyte interface from the fuel inlet to the fuel outlet of the cell. SEM images recorded along the electrode/electrolyte interface (at the fuel inlet, in the middle, and the fuel outlet) are reported in the supplementary materials (Figure S3 and Figure S4). Microstructural differences could not be observed from simple visual inspection of the images at the inlet and outlet side. We have previously analyzed the down stream variations in microstructural aging in a very similar set of samples. Results can be found in references $[15,51]$.

\section{$\underline{4.3 \text { Driving force for Ni migration }}$}

The depletion of Ni close to the electrode/electrolyte interface has already been observed and discussed in several studies in the literature [15, 43, 46-51]. However, the mechanisms of the Ni migration are not completely understood. Mogens et al. [43] proposed that the driving force for the Ni migration is the formation of $\mathrm{Ni}(\mathrm{OH})_{\mathrm{x}}$ volatile species which diffuse down the steam partial pressure gradients. In this section, we present an alternative explanation of the phenomenon of Ni migration based on postulating a variation in the $\mathrm{Ni} / \mathrm{YSZ}$ contact angle with local oxygen potential, which leads to a transport of $\mathrm{Ni}$ when an oxygen potential gradient is established in the electrode and interface is pulled out of equilibrium with the gas phase during operation.

At high temperatures, $\mathrm{Ni}$ atoms diffuse along the surface of the Ni network from regions characterized by high chemical potential towards regions of low chemical potential until the free energy of the system is minimized [59]. In simple two-phase systems, spatial gradients of chemical potential result from gradients of surface curvature [59]. In the case of Ni coarsening in Ni/YSZ electrodes, the chemical potential is also a function of the different interface energies 
present at each interface (i.e Ni-pore, Ni-YSZ, and YSZ-pores). In the proximity of the triple junctions (corresponding to the TPBs), the balance of these interface energies determines the $\mathrm{Ni} / \mathrm{YSZ}$ contact angle.

It has been reported that the contact angle is a function of the oxygen partial pressure $\left(\mathrm{pO}_{2}\right)$ [60]. The $\mathrm{pO}_{2}$ in the electrode is established by the equilibrium between $\mathrm{H}_{2}, \mathrm{H}_{2} \mathrm{O}$ and $\mathrm{O}_{2}$ according to the equation:

$$
p O_{2}=\frac{1}{K_{H}}\left(\frac{p H_{2} O}{1-p H_{2} O / P t o t}\right)
$$

where $K_{\mathrm{H}}$ is the equilibrium constant for the $\mathrm{H}_{2} / \mathrm{O}_{2}$ reaction and equal to $2.33 \times 10^{18}$ at $800{ }^{\circ} \mathrm{C}$ [60]. The dependency of the Ni/YSZ contact angle on $\log \left(\mathrm{pO}_{2}\right)$ is shown in Figure 8 (black solid line) and was obtained applying the procedure reported by Jiao et al. [60].

During cell operation, $\mathrm{p}\left(\mathrm{H}_{2} \mathrm{O}\right)$ and $\mathrm{p}\left(\mathrm{H}_{2}\right)$ gradients arise in the fuel electrode in the direction perpendicular to the electrode/electrolyte interface $[43,60]$. The local gas composition varies in the electrode due to the electrochemical reactions occurring at the TPB producing steam when operating in fuel cell mode and hydrogen in electrolysis mode. Regions of the electrode where the contact angle assumes lower values (high wettability) are characterized by lower chemical potential compared to regions having higher contact angles. Therefore, it is reasonable to assume that the gradient in contact angle due to the gradient in $\mathrm{pO}_{2}$ causes the migration of $\mathrm{Ni}$ atoms from low wettability regions towards high wettability regions (i.e. from high to low chemical potential). Computing the exact gas distribution $\left(\mathrm{pH}_{2} \mathrm{O} / \mathrm{pH}_{2}\right)$ in the electrode is not trivial and requires an accurate three-dimensional model of the cell operation. Here we assume that the gas composition at the gas channel is equal to the nominal composition of the inlet gas $\left(\mathrm{pH}_{2} \mathrm{O} / \mathrm{pH}_{2}=0.5 / 0.5\right)$ while the $\mathrm{pO}_{2}$ at the electrode/electrolyte interface can be estimated from the cell overpotential by using the relation [39] relating the overpotential to the $\mathrm{pO}_{2}$ variation via Nernst law: 


$$
\eta_{N i / Y S Z}=\frac{-R T}{4 F} \ln \left(\frac{\left(p\left(O_{2}\right)_{\text {Local GaS }}\right)}{\left(p\left(O_{2}\right)_{N i / Y S Z}\right)}\right)
$$

In Eq. $2 \eta_{N i / Y S Z}$ is the fuel electrode polarization, $R$ is the universal gas constant equal to 8.314 $\mathrm{J} \mathrm{K}^{-1} \mathrm{~mol}^{-1}$ and $\mathrm{F}$ is the Faraday constant equal to $96485 \mathrm{C} \mathrm{mol}^{-1}$. The local gas composition in the direction perpendicular to the electrode/electrolyte interface generates a gradient of $\left(\mathrm{pO}_{2}\right)_{\text {Local Gas }}$ in the same direction. The gradient is different between the two modes of operation, in SOFC mode steam is generated close to the electrolyte and in SOEC mode this is the place of hydrogen generation hence different partial pressure distributions prevail in the gas phase $\left(\left(\mathrm{pO}_{2}\right)_{\text {Local Gas }}\right)$ in the two modes. In addition, and more important, the local electrical polarization pulls the interface out of equilibrium with the gas phase in direction of more oxidizing conditions in SOFC and SOEC mode, respectively (this is a more significant effect in terms of equivalent $\mathrm{pO}_{2}$ variation than the variations in the gas phase due to steam and hydrogen partial pressure gradients). As a result the, $\mathrm{pO}_{2}$ values at the electrode/electrolyte interface estimated via Equation 2 will be significantly different between the two cases. The overpotential of the Ni/YSZ electrode for the two tested cells (SOFC and SOEC) is estimated from electrochemical impedance spectroscopy analysis where the measured impedance corresponds to fuel electrode overpotential ranges of $0.03-0.09 \mathrm{~V}$ and $-(0.11-0.26) \mathrm{V}$ for SOFC and SOEC, respectively. One vertical line and two marked areas are plotted in Figure 8 for the $\log \left(\mathrm{pO}_{2}\right)$ value computed for the gas channel (green line), the electrode/electrolyte interface obtained for the SOEC (red area) and the SOFC (blue area). Figure 8 illustrates that, in SOEC mode, the electrode/electrolyte interface presents a higher contact angle compared to the region in the proximity of the gas channel. Therefore, accordingly, Ni should migrate from the active electrode towards the support layer, as observed experimentally in this work and in previous studies [15, 43]. 
Interestingly, in SOFC mode, the contact angle at the electrode/electrolyte interface is lower than in the region close to the gas channel. Therefore, following our hypothesis, Ni should migrate from the support enriching the active electrode. Furthermore, assuming the values of $\mathrm{pO}_{2}$ at the electrode/electrolyte interface obtained from the electrode overpotential, a greater difference in contact angle between the gas channel and the active electrode is observed for the SOFC case. Therefore, a higher driving force for Ni migration should be expected (assuming the contact angle $\mathrm{pO}_{2}$ relationship postulated in reference [60]). However, a $\mathrm{Ni}$ enrichment of the active electrode in the SOFC is clearly not observed here.

Several reasons can lead to the mismatch between above hypothesis on local contact angle variations as the Ni migration driver and the experimental observations in the SOFC case. Firstly, the Ni migration from the electrode/support interface towards the electrode/electrolyte interface would likely lead to the Ni enrichment in the electrode region close to the electrolyte, causing increase in Ni phase fraction and Ni mean radii. Contrarily to the SOEC case, where $\mathrm{Ni}$ depletion can be easily observed at the electrode/electrolyte interface, the enrichment of $\mathrm{Ni}$ at the electrode/electrolyte interface can be more challenging to detect. This is due to the fact that an increase in Ni phase fraction and Ni continuous PSD could be small and below the sensitivity in the imaging techniques employed in this work.

More importantly, a big uncertainty remains in the dependence of the Ni/YSZ contact angle on $\log \left(\mathrm{pO}_{2}\right)$ proposed by Jiao et al. [60], i.e. the black solid line in Figure 8. In their work, the enhanced Ni wettability on YSZ was experimentally observed under SOFC polarization only, i.e. for values of $\mathrm{pO}_{2}>10^{-19}$ bar. The procedure introduced by Jiao et al. [60] is used here to obtain the black solid line shown in Figure 8 in the $\log \left(\mathrm{pO}_{2}\right)$ range from -25 to -17 , approximately. However, this part of curve, corresponding to SOEC polarization, has not been experimentally validated. In fact, it is unlikely that a dependence like the one depicted in Figure 8 imposes contact angle variations large enough across the active Ni/YSZ electrode to result 
in the observed Ni migration. A much steeper slope of the curve for $\mathrm{pO}_{2}<10^{-19}$ bar is therefore required as indicated by the stronger postulated dependence illustrated by the black dashed curve in Figure 8. In addition, the current authors have recently succeeded in reproducing $\mathrm{Ni}$ migration in SOEC mode via phase field simulations (the results will be reported elsewhere). The Ni migration is achieved in the model calculations by imposing a large postulated contact angle gradient $\left(95-120^{\circ}\right)$ across the active Ni/YSZ electrode. This would imply that the contact angle variations over a polarized electrode are stronger than predicted from the methods suggested in reference [60] as indicated by the postulated curve included in Figure 8 . Future experimental determination of the $\mathrm{Ni} / \mathrm{YSZ}$ contact angle as a function of local $\mathrm{pO}_{2}$ is required to confirm or veto our hypothesis that the Ni migration is driven by spatial variations in Ni/YSZ contact angle that are introduced by polarizing the electrode and that these variations are very significant over an electrode strongly polarized in SOEC direction. It should be noted that in the SOEC-range it is not trivial to measure the contact angle as such reducing conditions are experimentally difficult to realize. In the SOFC-range one can investigate samples in different gas-mixtures realizing the relevant oxygen activities. In the range relevant for strongly polarized electrodes operating in electrolysis mode the oxygen activity requires electrochemical polarization. It would require development of a specially dedicated methodology enabling simultaneous assessment of contact angle and accurate control of polarization. Another strategy to arrive at the wetting angle under strong cathodic polarization is to try and deduce it from the reconstructions - analyzing the pictures and the contact angles experienced in the microstructures aged under polarization, which are pursued by the current authors. 


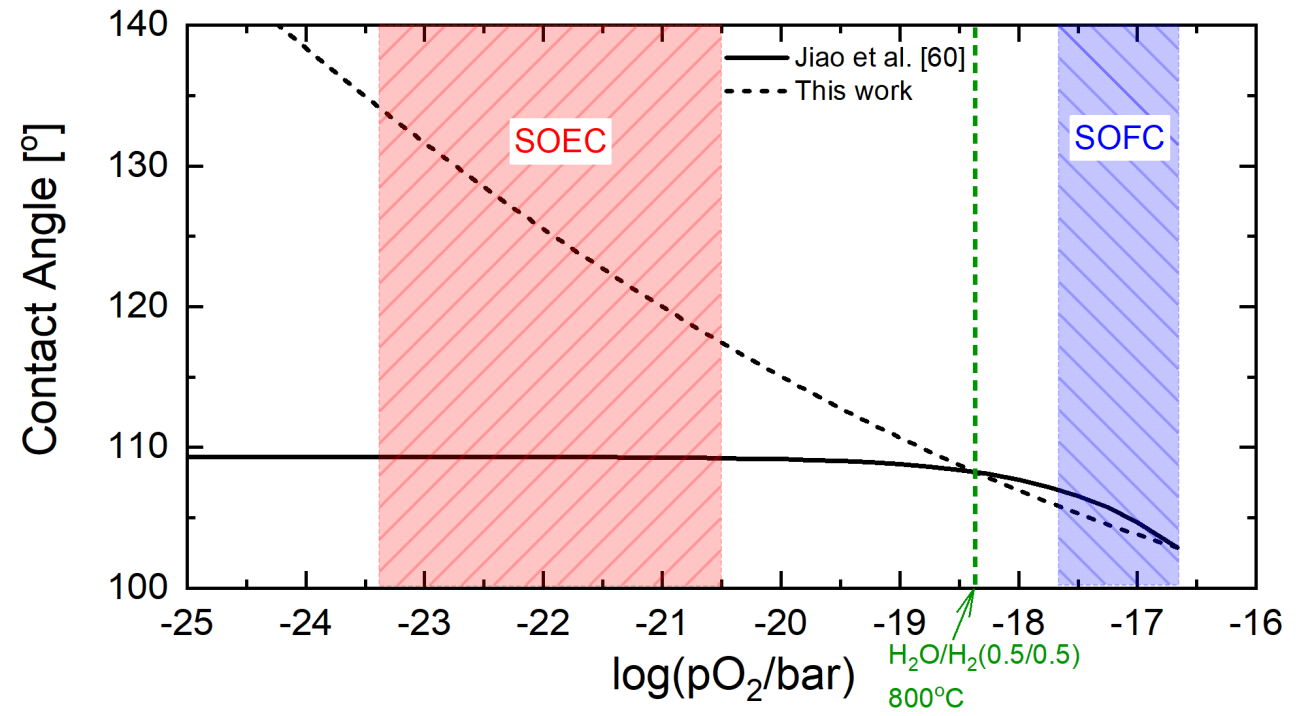

Figure 8: Relation between contact angle and $\log \left(\mathrm{pO}_{2}\right)$ with the $\log \left(\mathrm{pO}_{2}\right)$ value obtained for the fuel gas composition at the inlet side $\left(\mathrm{pH}_{2} \mathrm{O} / \mathrm{pH}_{2}=0.5 / 0.5\right)$ (green line) and the $\log \left(\mathrm{pO}_{2}\right)$ ranges for the SOEC and the SOFC overpotentials at the electrode/electrolyte interface (red and blue areas, respectively).

\section{Conclusion}

In this work, we examined the $\mathrm{Ni} / \mathrm{YSZ}$ electrode microstructure of two nominally identical cells tested for $1000 \mathrm{~h}$, one in SOFC mode and the other in SOEC mode. Identical operating conditions (i.e. $800^{\circ} \mathrm{C}$ and $\mathrm{p}\left(\mathrm{H}_{2} \mathrm{O}\right) / \mathrm{p}\left(\mathrm{H}_{2}\right)=0.5 / 0.5$ at the fuel inlet side) were applied varying the direction of the current $\left(1 \mathrm{~A} \mathrm{~cm}^{-2}\right.$ for SOFC and $-1 \mathrm{~A} \mathrm{~cm}^{-2}$ for SOEC). The analysis highlights a more pronounced performance degradation and Ni/YSZ microstructure change of the SOEC compared to SOFC. Similar Ni particle size distributions were observed for the two aged cells indicating that Ni coarsening is not affected by the mode of operation. In addition, interface and surface areas computed for the SOFC and the SOEC show only minor differences that can be considered to be in the margin of error of the measurement.

On the other hand, a significant Ni migration away from the electrode/electrolyte interface was detected only for the SOEC case. Ni migration in the SOEC leads to loss of percolating nickel and an increase in the porosity in the active region of the fuel electrode. Furthermore, the more 
pronounced decrease of the SOEC total and percolating TPB density will affect the electrical performance of the cell. From the results we emphasize that local Ni depletion should be considered a major source of the SOEC performance degradation.

A hypothesis on the driving force generating the depletion of $\mathrm{Ni}$ in the active fuel electrode is presented. In SOEC mode, Ni diffuses from the electrode/electrolyte interface towards the support. The $\mathrm{Ni}$ moves from the position of very low $\mathrm{pO}_{2}$ (strongly polarized zone close to the electrolyte) where the Ni/YSZ contact angle is high (de-wetting) towards the higher $\mathrm{pO}_{2}$ in the outer parts of the electrode, that are less polarized and where also the gas phase $\mathrm{pO}_{2}$ is higher, resulting in a locally lower $\mathrm{Ni} / \mathrm{YSZ}$ contact angle (wetting behavior).

\section{Acknowledgments}

This work was financially supported by the projects "Synfuel" (4106-00006B) from Innovation Fund Denmark and EUDP project no. 64017-0011 "EP2Gas - Efficient Power2Gas combining SOEC and biomass gasification". Moreover, the authors would like to thank Senior Researcher Peter Stanley Jørgensen for his technical support.

\section{References}

[1] S. D. Ebbesen, S. H. Jensen, A. Hauch, and M. B. Mogensen, High Temperature Electrolysis in Alkaline Cells, Solid ProtonConducting Cells, and Solid Oxide Cells, Chem. Rev. 114, 10697-10734, 2014.

[2] C. Graves, S. D. Ebbesen, M. Mogensen, K. S. Lackner, Sustainable hydrocarbon fuels by recycling $\mathrm{CO} 2$ and $\mathrm{H} 2 \mathrm{O}$ with renewable or nuclear energy, Ren. Sust. Energ. Rev. 15, 1-23, 2011.

[3] A. Smith, A. S. Pedersen, Fuel Cells, Encyclopedia of Environmental Management DOI: 10.1081/E-EEM-120050576, 2014. 
[4] A. Smith, A. Schrøder Pedersen, Electrolysis, Encyclopedia of Environmental Management DOI: 10.1081/E-EEM-120050577, 2014.

[5] A. Hauch, K. Brodersen, F. Karas, and M. Chen, Ni/YSZ microstructure optimization for long-term stability of solid oxide electrolysis cells, Chapter 12 - Session B06 - 88/183, 1 - 4 July 2014, Lucerne/Switzerland, 2014.

[6] A. Hauch, S. D. Ebbesen, S. H. Jensen, and M. Mogensen, Solid Oxide Electrolysis Cells: Microstructure and Degradation of the Ni/Yttria-Stabilized Zirconia Electrode, J. Electrochem. Soc. 155(11), B1184-B1193, 2008.

[7] C. Graves, S. D. Ebbesen, S. H. Jensen, S. B. Simonsen, and M. B. Mogensen, Eliminating degradation in solid oxide electrochemical cells by reversible operation, Nat. Mater. Vol. 14, 239-244, 2015.

[8] A. Ringuedé, D. P. Fagg, J.R. Frade, Electrochemical behaviour and degradation of $(\mathrm{Ni}, \mathrm{M}) / \mathrm{YSZ}$ cermet electrodes $(\mathrm{M}=\mathrm{Co}, \mathrm{Cu}, \mathrm{Fe})$ for high temperature applications of solid, electrolytes, Journal of the European Ceramic Society 24, 1355-1358, 2004.

[9] F. Tietz a, D. Sebold, A. Brisse, J. Schefold, Degradation phenomena in a solid oxide electrolysis cell after 9000 h of operation, J. Power Sources 223, 129-135, 2013.

[10] P. Tanasini1, M. Cannarozzo, P. Costamagna, A. Faes, J. Van Herle, A. Hessler-Wyser, and C. Comninellis, Experimental and Theoretical Investigation of Degradation Mechanisms by Particle Coarsening in SOFC Electrodes, Fuel Cells 09 No. 5, 740-752, 2009.

[11] Z. Jiao, N. Shikazono, and N. Kasagi, Quantitative Characterization of SOFC Nickel-YSZ Anode Microstructure Degradation Based on Focused-Ion-Beam 3D-Reconstruction Technique, J. Electrochem. Soc. 159 (3), B285-B291, 2012. 
[12] D. Kennouche, Y.-C. Karen Chen-Wiegart, J. S. Cronin, J. Wang, and S. A. Barnett, Three-Dimensional Microstructural Evolution of Ni-Yttria-Stabilized Zirconia Solid Oxide Fuel Cell Anodes At Elevated Temperatures, J. Electrochem. Soc. 160 (11), F1293-F1304, 2013.

[13] O. M. Pecho, A. Mai, B. Münch, T. Hocker, Robert J. Flatt, and L. Holzer, 3D Microstructure Effects in Ni-YSZ Anodes: Influence of TPB Lengths on the Electrochemical Performance, Materials 8, 7129-7144, 2015.

[14] S. De Angelis, P. S. Jørgensen, E. H. R. Tsai, M. Holler, K. Kreka, J. R. Bowen, Three dimensional characterization of nickel coarsening in solid oxide cells via ex-situ ptychographic nano-tomography, J. Power Sources 383, 72-79, 2018.

[15] M. Trini, P. S. Jørgensen, A. Hauch, J. J. Bentzen, P. V. Hendriksen, and M. Chen, 3D Microstructural Characterization of Ni/YSZ Electrodes Exposed to 1 Year of Electrolysis Testing, J. Electrochem. Soc. 166 (2), F1-F10, 2019.

[16] E. Lay-Grindler, J. Laurencin, J. Villanova, P. Cloetens, P. Bleuet, A. Mansuy, J. Mougin, G. Delette, Degradation study by 3D reconstruction of a nickeleyttria stabilized zirconia cathode after high temperature steam electrolysis operation, J. Power Sources 269, 927-936, 2014.

[17] G. J. Nelson, K. N. Grew, J. R. Izzo Jr. J. J. Lombardo,W. M. Harris, A. Faes, A. HesslerWyser, J. Van Herle, S. Wang, Y. S. Chu, A. V. Virkar, W. K. S. Chiu, Three-dimensional microstructural changes in the Ni-YSZ solid oxide fuel cell anode during operation, Acta Mater. 60, 3491-3500, 2012. 
[18] L. Holzer, B. Iwanschitz, Th. Hocker, B. Münch, M. Prestat, D. Wiedenmann, U. Vogt, P. Holtappels, J. Sfeir, A. Mai, Th. Graule, Microstructure degradation of cermet anodes for solid oxide fuel cells: Quantification of nickel grain growth in dry and in humid atmospheres, J. Power Sources 196, 1279-1294, 2011.

[19] J. Laurencin, R. Quey, G. Delette, H. Suhonen, P. Cloetens, P. Bleuet, Characterisation of Solid Oxide Fuel Cell Ni-8YSZ substrate by synchrotron X-ray nano-tomography: from 3D reconstruction to microstructure quantification, J. Power Sources 198, 182- 189, 2012.

[20] M. Hubert, J. Laurencin, P. Cloetens, B. Morel, D. Montinaro, F. Lefebvre-Joud, Impact of Nickel agglomeration on Solid Oxide Cell operated in fuel cell and electrolysis modes, J. Power Sources 397, 240-251, 2018.

[21] P. S. Jørgensen, J. R. Bowen, Determination of Three Dimensional Microstructure Parameters from a Solid Oxide Ni/YSZ Electrode after Electrolysis Operation, ECS Transaction 35 (1), 1655-1660, 2011.

[22] D. The, S. Grieshammer, M. Schroeder, M. Martin, M. Al Daroukh, F. Tietz, J. Schefold, A. Brisse, Microstructural comparison of solid oxide electrolyser cells operated for $6100 \mathrm{~h}$ and 9000 h, J. Power Sources 275, 901-911, 2015.

[23] G. Rinaldi, S. Diethelm, E. Oveisi, P. Burdet, J. Van Herle, D. Montinaro, Q. Fu, A. Brisse, Post-test Analysis on a Solid Oxide Cell Stack Operated for 10,700 Hours in Steam Electrolysis Mode, Fuel Cells 17 No. 4, 541-549, 2017.

[24] Q. Fang, C. E. Frey, N. H. Menzler, and L. Blum, Electrochemical Performance and Preliminary Post-Mortem Analysis of a Solid Oxide Cell Stack with 20,000 h of Operation, J. Electrochem. Soc., 165 (2), F38-F45, 2018. 
[25] M. P. Hoerlein, M. Riegraf, R. Costa, G. Schiller, K. A. Friedrich, A parameter study of solid oxide electrolysis cell degradation: Microstructural changes of the fuel electrode, Electrochim. Acta 276, 1062-175, 2018.

[26] S. Zha, Z. Cheng, and M. Liu, Sulfur Poisoning and Regeneration of Ni-Based Anodes in Solid Oxide Fuel Cells, J. Electrochem. Soc., 154 (2), B201-B206, 2007.

[27] Z. Cheng, and S. Zha, M. Liu, Influence of cell voltage and current on sulfur poisoning behavior of solid oxide fuel cells, J. Power Sources 172, 688-693, 2007.

[28] K. Sasaki, K. Susuki, A. Iyoshi, M. Uchimura, N. Imamura, H. Kusaba, Y. Teraoka, H. Fuchino, K. Tsujimoto, Y. Uchida, and N. Jingo, H2S Poisoning of Solid Oxide Fuel Cells, J. Electrochem. Soc., 153 (11), A2023-A2029, 2006.

[29] A. Hagen, J. F.B. Rasmussen, and K. Thydén, Durability of solid oxide fuel cells using sulfur containing fuels, J. Power Sources 196, 7271- 7276, 2011.

[30] S. D. Ebbesen, C. Graves, and M. Mogensen, Production of Synthetic Fuels by CoElectrolysis of Steam and Carbon Dioxide, Int. J. Green Energy 6, 646-660, 2009.

[31] M. D. Gross, J. M. Vohs, and R. J. Gorte, Recent progress in SOFC anodes for direct utilization of hydrocarbons, J. Mater. Chem. 17, 3071-3077, 2007.

[32] J. Mermelstein, M. Millan-Agorio, and N. P. Brandon, The impact and mitigation of carbon formation on Ni-YSZ anodes from biomass gasification tars, ECS Transactions 17 (1), 111-117, 2009. 
[33] W. Li, Y. Shi, Y. Luo, Y. Wang, and N. Cai, Carbon deposition on patterned nickel/yttria stabilized zirconia electrodes for solid oxide fuel cell/solid oxide electrolysis cell modes, J. Power Sources 276, 26-31, 2015.

[34] J.-H. Koh, Y.-S. Yoo, J.-W. Park, and H. C. Lim, Carbon deposition and cell performance of Ni-YSZ anode support SOFC with methane fuel, Solid State Ionics 149, 157- 166, 2002.

[35] Y. Matsuzaki, and I. Yasuda, The poisoning effect of sulfur-containing impurity gas on a SOFC anode: Part I. Dependence on temperature, time, and impurity concentration, Solid State Ionics 132, 261-269, 2000.

[36] K. V. Jensen, R. Wallenberg, I. Chorkendorff, and M. Mogensen, Effect of impurities on structural and electrochemical properties of the Ni-YSZ interface, Solid State Ionics 160, $27-$ $37,2003$.

[37] V. Duboviks, R. C. Maher, M. Kishimoto, L. F. Cohen, N. P. Brandon, and G. J. Offer, A Raman spectroscopic study of the carbon deposition mechanism on Ni/CGO electrodes during CO/CO2 electrolysis, Phys.Chem.Chem.Phys. 16, 13063, 2014.

[38] A. Hauch, K. Brodersen, M. Chen, C. Graves, S. H. Jensen, P. S. Jørgensen, P. V. Hendriksen, M. B. Mogensen, S. Ovtar, and X. Sun, A Decade of Solid Oxide Electrolysis Improvements at DTU Energy, ECS Transactions 75 (42), 3-14 (2017), 2017.

[39] M. Chen, Y.-L. Liu, J. J. Bentzen, W. Zhang, X. Sun, A. Hauch, Y. Tao, J. R. Bowen, and P. V. Hendriksen, Microstructural Degradation of Ni/YSZ Electrodes in Solid Oxide Electrolysis Cells under High Current, J. The Electrochem. Soc. 160 (8), F883-F891, 2013. 
[40] G. Schiller, A. Ansar, M. Lang, and O. Patz, High temperature water electrolysis using metal supported solid oxide electrolyser cells (SOEC), J. Appl. Electrochem. 39, 293-301. 2016.

[41] M. Keane, H. Fan, M. Han, P. Singh, Role of initial microstructure on nickel-YSZ cathode degradation in solid oxide electrolysis cells, Int. J. Hydrogen Energ. 39, 18718-18726, 2014.

[42] K. Chen and S. P. Jiang, Review Materials Degradation of Solid Oxide Electrolysis Cells, J. The Electrochem. Soc., 163 (11), F3070-F3083, 2016.

[43] M. B. Mogensen, A. Hauch, X. Sun, M. Chen, Y. Tao, S. D. Ebbesen, K. V. Hansen, and P. V. Hendriksen, Relation Between Ni Particle Shape Change and Ni Migration in Ni-YSZ Electrodes - a Hypothesis, Fuel Cells 17 (4), 434-441, 2017.

[44] A. Nakajo, A. P. Cocco, M. B. Degostin, P. Burdet, A. A. Peracchio, B. N. Cassenti, M. Cantoni, J. Van Herle, W. K. S. Chiu, Evolution of 3-D Transport Pathways and Triple-Phase Boundaries in the Ni-YSZ Hydrogen Electrode upon Fuel Cell or Electrolysis Cell Operation, ECS Transactions 78 (1), 3205-3215, 2017.

[45] X. Sun, M. Chen, Y. L. Liu, and P. V. Hendriksen, Life Time Performance Characterization of Solid Oxide Electrolysis Cells for Hydrogen Production, ECS Transactions 68 (1), 3359-3368, 2015.

[46] A. Hauch, K. Brodersen, M. Chen, M. B. Mogensen, Ni/YSZ electrodes structures optimized for increased electrolysis performance and durability, Solid State Ionics 293, 27-36, 2016 
[47] X. Sun, M. Chen, P. V. Hendriksen, and M. B. Mogensen, Durable solid oxide electrolysis cells for hydrogen production, Chapter 16 - Session B13 - 41/151, 1 - 4 July 2014, Lucerne/Switzerland, 2014.

[48] P. Hjalmarsson, X. Sun, Y.-L. Liu, and M. Chen, Durability of high performance Ni-yttria stabilized zirconia supported solid oxide electrolysis cells at high current density, J. Power Sources 262, $316-322,2014$.

[49] S. Ovtar, X. Tong, J. J. Bentzen, K. T. S. Thydén, S. B. Simonsen, and M. Chen, Boosting the performance and durability of Ni/YSZ cathode for hydrogen production at high current densities via decoration with nano-sized electrocatalysts, Nanoscale 11, 4394, 2019.

[50] X. Tong, S. Ovtar, K. Brodersen, P. V. Hendriksen, and M. Chen, A $4 \times 4 \mathrm{~cm}^{2}$ Nanoengineered Solid Oxide Electrolysis Cell for Efficient and Durable Hydrogen Production, ACS Appl. Mater. Interfaces 11, 25996 - 26004, 2019.

[51] M. Trini, P. S. Jørgensen, A. Hauch, M. Chen, P. V. Hendriksen, Microstructural Characterization of Ni/YSZ Electrodes in a Solid Oxide Electrolysis Stack Tested for 9000 Hours, ECS Transactions 78 (1), 3049-3064, 2017.

[52] Montgomery, Douglas C. Design and analysis of experiments. John Wiley \& sons, pp. 105-108, 2017.

[53] K. Thydén, Y.L. Liu, J.B. Bilde-Sørensen, Microstructural characterization of SOFC NiYSZ anode composites by low-voltage scanning electron microscopy, Solid State Ionics 178, 1984-1989, 2008. 
[54] P.S. Jørgensen, S.L. Ebbehøj, A. Hauch, Triple phase boundary specific pathway analysis for quantitative characterization of solid oxide cell electrode microstructure, J. Power Sources 279, 686-693, 2015.

[55] B. Münch and L. Holzer, Contradicting Geometrical Concepts in Pore Size Analysis Attained with Electron Microscopy and Mercury Intrusion, J. Am. Ceram. Soc. 91 (12), 40594067, 2008.

[56] J. R. Wilson, J. S. Cronin, and S. A. Barnett, Linking the microstructure, performance and durability of Ni-yttria-stabilized zirconia solid oxide fuel cell anodes using three-dimensional focused ion beam-scanning electron microscopy imaging, Scripta Mater. 65, 67-72, 2011.

[57] T. Matsui, R. Kishida, J.-Y. Kim, H. Muroyama, and K. Eguchi, Performance Deterioration of Ni-YSZ Anode Induced by Electrochemically Generated Steam in Solid Oxide Fuel Cells, J. Electrochem. Soc., 157 (5), B776-B781, 2010.

[58] R. Knibbe, M. L. Traulsen, A. Hauch, S. D. Ebbesen, and M. Mogensen, Solid Oxide Electrolysis Cells: Degradation at High Current Densities, J. Electrochem. Soc. 157 (8), B1209B1217, 2010.

[59] H.-Y. Chen, H.-C. Yu, J. S. Cronin, J. R. Wilson, S. A. Barnett, K. Thornton, Simulation of coarsening in three-phase solid oxide fuel cell anodes, J. Power Sources, 196, 1333-1337, 2011.

[60] Z. Jiao, N. Shikazono, Study on the effects of polarization on local morphological change of nickel at active three-phase-boundary using patterned nickel-film electrode in solid oxide fuel cell anode, Acta Mater. 135, 124-131, 2017. 